\title{
Work Stress among Professionals in the Building Construction Industry in Nigeria
}

Eziyi Offia Ibem, Michael Nwabueze Anosike, Dominic Ezenwa Azuh, and Tim O. Mosaku, (Covenant University, Ota, Nigeria)

\begin{abstract}
This study was undertaken to identify key stress factors among professionals in the building construction industry in Nigeria. This is in view of the fact that to date, very little is known about work stress among professionals in the building construction industry in this country. The study involved the administration of a questionnaire to 107 professionals including architects, builders, civil/structural engineers and quantity surveyors randomly selected from 60 ongoing building projects in Anambra, Ogun and Kaduna States, Nigeria. The data were analysed using descriptive statistics, and findings show that the principal sources of stress were high volume of work, uncomfortable site offices, lack of feedback on previous and ongoing building projects, and variations in the scope of work in ongoing building projects. The paper suggests that taking responsibility for work which one has adequate capacity to handle, establishing realistic budgets and time frames for project delivery, provision of spatially adequate, visually and thermally comfortable site offices, adoption of appropriate job design practices and education of professionals in stress management will reduce the incidence of stress among professionals in the building industry in Nigeria.
\end{abstract}

Keywords: Work stress, Building construction Industry, Professionals, Nigeria

\section{Introduction}

In the last few decades, the building construction industry has witnessed tremendous institutional and organizational transformation across the globe. Continuous modification of building process, pace and complexity of work and increasing demand for higher productivity have become common features of this industry. These are in response to globalization of economy and markets, technological advancement and changing consumer preferences. In fact, the dynamic and complex nature of construction works, diverse backgrounds and hostile attitudes of participants are also believed to be contributing greatly to rapid changes taking place within the construction industry in general (Wong et al, 2010). As a result, professionals and indeed the work force in this sector operate in an extremely competitive environment where projects are designed, constructed and delivered within tight budgets and time frames. All these have combined to make construction work mentally and emotionally demanding and stressful (Wahab, 2010).

Work stress is known to impact negatively on productivity and job satisfaction among workers in different professions (McVicara, 2003; $\mathrm{Ng}$ et al., 2005; Haq et al., 2008; Lath, 2010). It is also believed to be a major contributor to absenteeism, low employee morale, high accident and turnover rates as well as increasing medical expenses of many organizations (Wahab, 2010). Hence, research into job-related stress has increased in recent years (Whetten and Cameron, 1991). Notably, previous studies have shown that work stress can be physically and mentally harmful to workers and it is related to physical condition, organizational structure, interpersonal conflict, personal characteristics and nature of work ( $\mathrm{Ng}$ et al., 2005, Haq et al., 2008; Lath, 
2010). There is also evidence in the literature suggesting that occupational stress has manifested itself in unsafe working practices, decrease in the quantity and quality of performance at work and reduction in performance accuracy (Loosemore and Waters, 2004; Melia and Becerril, 2007; Halkos and Bousinakis, 2010). Therefore, there is a consensus that intense, continuous and repeated work stress can be inimical to individual and organizational productivity and competiveness in job performance, and thus deserves more research attention.

Stress is not limited to any particular profession ( $\mathrm{Ng}$ et al., 2005; Lath, 2010). However, Statt (1994) noted that construction work is the third most stressful profession after mining and police work. Specifically, Campbell (2006) found that in the United Kingdom, construction professionals were increasingly viewing their work as being stressful. Linda et al (2003) identified the nature of production processes that take place in the construction industry as being responsible for making construction work a dangerous and stressful occupation. This goes to suggest that work stress is a major threat to the attainment of sustainable growth in the construction industry in particular and economic development of any nation in general.

There is a growing body of research literature on occupational stress among professionals and workers in the construction industry as previous studies suggest (Campbell, 2006; Leung, et al., 2007; Lingard et al., 2006; Leung et al., 2008; 2010) . Interestingly, this body of contemporary literature has advanced our understanding on the causes of stress and how construction professionals in the West and Asia were coping with it. They however do not provide adequate insight on the situation among professionals in the building construction industry in Africa. In particular, the review of literature shows that very little research has examined stress factors among professionals in the building construction industry in Nigeria.

Since stress perception is highly subjective and varies from one individual and context to another (Wong et al., 2010), there is bound to be variation among professionals in the building construction industry in their perception of stress factors. This no doubt has implications for stress management strategies in the construction industry in general. Also the urgency of attaining sustainable growth and national development calls for more studies on work stress, especially in developing countries, including Nigeria. This paper reports on the result of research aimed at identifying stress factors among professionals in the building construction industry in Nigeria. It identifies the key stress factors among architects, builders, civil engineers and quantity surveyors directly involved in building construction projects in Nigeria. Based on the findings, it suggests strategies to eliminate or reduce stress factors among professionals in the industry in this country.

\section{Review of related Literature}

The concept of stress has a long tradition in organizational and social literature (Somerfield and McCrae, 2000). However, evidence in contemporary literature shows that stress has been defined and viewed from diverse perspectives. Aitken and Crawford (2007) noted that the exploration of the concept of stress began with the work of Hans Selye in 1936. Selye in his work defined stress as the force, pressure, or strain exerted upon an object or a person that resists these forces and attempts to maintain its original state. He conceived of stress as a pathological human response to psychological, social, occupational and/or environmental pressures; and therefore concluded that stress is neither a simple nervous tension resulting from damage nor necessarily something to be avoided (Selye, 1978). Drawing from Selye's submissions, Pulat (1997) and Martino and Musri (2001) opined that some amount of stress is necessary to generate enthusiasm and creativity for optimal productivity. They however cautioned that intense or too much stress in work environment poses great risk to workers' safety, health and emotional stability. The foregoing submissions tend to suggest that stress is

Ibem, E 0 et al. (2011) 'Work stress among professionals in the building construction industry in Nigeria', Australasian Journal of Construction Economics and Building, 11 (3) 45-57 
an unavoidable consequence of modern living and is not necessarily a negative phenomenon as long as it is within a tolerable level that can engender enthusiasm, creativity and productivity.

Melia and Becerril (2007) on the other hand indicated that stress is an experience expressed in one's feeling of being strained while the Health and Safety Executive (HSE, 2007) defined stress as the adverse reaction people have due to excessive pressure or other types of demand placed on them. Put differently, Lath (2010) was of the view that every person including a child, an adult, employed or unemployed faces stress in his/her everyday life. He defined stress as any challenge that exceeds the coping abilities of the individual. From the occupational perspective, stress has also been defined as the physical and emotional responses that occur when workers perceive an imbalance between their work demands and their capability to meet such demands. In other words, stress is a harmful physical and emotional response that can occur when there is conflict between job demands on a worker and his/her capacity to meet such demands (Brown, 2001; Lath, 2010). The general inference that can be drawn from the foregoing definitions is that stress can be considered as an inevitable and unavoidable component of life. It can also be inferred that occupational or work stress is the type of stress experienced as a direct consequence of a person's occupation. Therefore, in this study, work stress is viewed as a human perception of conditions that scare, excite, annoy, threaten or strain individuals as a result of their occupation.

In view of evidence in the literature on the negative consequences of stress among modern day work forces, a number of theoretical models on work stress have been developed. One such theory is the Person-Environment fit theory first proposed by French, Robert and Van Harrison in 1982. According to this theory, stress occurs as a result of an incongruity between the individual and the ambient environment (Melia and Becerril, 2007). The key elements of this model comprise objective and subjective variables that could be found in the environment or the person. Cox and Mackay (1979) were of the opinion that stress is a highly individual phenomenon which exists as a result of a person's appraisal of his/her involvement in the environment. They pointed out that stress arises as a result of an imbalance between the person's perception of the demand placed on him/her and his/her perception of ability to cope.

Occupational stress may also be seen as comprising a three-dimensional syndrome of emotional exhaustion, depersonalization and reduced personal accomplishment (Maslach et al., 1996). Stress in this context is seen as a state of physical, emotional and mental exhaustion due to long-term involvement in situations that are emotionally testing (Melia and Becerril, 2007). Maslach et al (2001) noted that individuals experiencing long periods of chronic job stress are likely to encounter physical and health problems, reduced productivity or effectiveness, lower levels of satisfaction and organizational commitment. This concept of stress suggests that long exposure to physically, mentally and emotionally testing activities could result in exhaustion which can lead to reduction in one's level of productivity and accomplishment.

The Demand-Control-Support Model developed by Karasek in 1979 is the most common approach to understanding stress and its effect on psychological and physical health. It focuses on the interaction between job demands and workers' potential control over their work schedule. In line with this theory, Anderson (1976) noted that work stress is a consequence of man's exposure to conflict with his fellow workers, disintegration of work process into isolated routines, shift work arrangement, automation, rapid technological change and urbanization. In essence, this model proposes that a combination of psychological job demands, decision making capacity, and social support in the work environment can help explain the various consequences of stress (Karasek and Theorell, 1990). This suggests that a combination of high job demand, low decision making capacity and social support, mechanization of work processes

Ibem, E 0 et al. (2011) 'Work stress among professionals in the building construction industry in Nigeria', Australasian Journal of Construction Economics and Building, 11 (3) 45-57 
as well as routine jobs can be sources of occupational stress, which is detrimental to people's health and productivity at work.

From the above theories, it can be inferred that the concept of work stress is viewed as a behavioural attribute that varies from one individual and context to another. It can also be inferred that work stress is a result of the gap between demands of the work environment and the capacity to cope with the challenges thereof (Brown, 2001; Lath, 2010). Also as a common attribute of working life, stress can become a negative phenomenon if workers are unable to cope and lack social support. This can ultimately lead to a state of physical, emotional and mental exhaustion resulting in low productivity at work. Viewed from a different perspective, several authors have also argued that stress can occur whenever there is a change in the equilibrium in man-machine -environment interaction, which may result in the distribution of generated stress among the components of a production system. Since man is known to be the weakest component of the work-environment system, most common signs of stress are manifested in some notable human responses such as crying, smoking, excessive eating, drinking alcohol, fast talking, fear, anxiety, guilt, anger, grief, depression and disgust (Lazarus, 1966; Leung et al, 2005; Yip et al., 2005; Wahab, 2010). In Hong Kong for instance, high levels of job burnout have been identified among construction professionals. This has threatened their well-being and reduced industrial efficiency and long-term competitiveness of construction professionals in that country (Yip et al., 2005). Similarly, Stress has also been identified as one of the root causes of low productivity of construction site workers (Dainty et al., 1999; Lingard and Francis, 2004; Wahab, 2010). Moreover, recent studies show that construction workers experienced much more stress at their work place than at home, and this had negative effects on their health and productivity at work (Wahab, 2010; Halkos and Bousinakis, 2010).

With regards to stress factors in the construction industry, Kenneth (2005) noted that construction project stress is the manifestation of factors that negatively erode values from the project, and thus make desired goal unattainable. Work overloads, working long hours and role ambiguity are known to be leading causes of stress amongst professionals in construction projects (Sutherland and Davidson, 1989). Statt (1994) asserted that multilevel subcontracting, time pressure; constant worker rotation and unstable work due to temporary contracts can contribute to psychosocial stress among workers. From a gender perspective, Loosemore and Waters (2004) found that male professionals in the construction industry suffer more stress in relation to risk taking, disciplinary matters and implications of mistakes, redundancy and career progression than their female counterparts while female professionals suffer stress due to opportunities for personal development, rate of pay, keeping with new ideas, business travel and accumulative effect of minor tasks. Previous studies shows that the general sources of stress among construction sector workers are quantitative work load, tight time schedule for work, lack of career guidance, poor communication among participants and bureaucracy. Others are inadequate room for innovation, unsatisfactory remuneration, ambiguity of job requirement, inadequate knowledge of project objectives, long working hours, tight schedules and unfavourable working conditions (Leiter, 1991; $\mathrm{Ng}$ et al., 2005).

Also Lin and Chan (2009) found that temperatures above $30^{\circ} \mathrm{C}$ and relative humidity above $74 \%$ posed health threats to construction workers in Taiwan. They noted that physically overloaded construction workers were among the most vulnerable to the negative impact of temperature on their health and productivity. Most recently, it was found that noise, cold, conflict with one another, unintended and unforeseen phenomena, search for optimal solutions consistent with client's budget and time frame, reaching comprises, moving and rearranging work schedules and other potentially intolerable conditions constitute stressors to workers in the construction industry in Nigeria (Wahab, 2010). Generally speaking, the sources of stress among workers in

Ibem, E 0 et al. (2011) 'Work stress among professionals in the building construction industry in Nigeria', Australasian Journal of Construction Economics and Building, 11 (3) 45-57 
the construction industry as found in contemporary literature can be classified into the five principal groups. Table 1 shows a checklist of the different work characteristics and associated stressors. It is evident from this Table that the key sources of stress include (i) personal characteristics related sources (ii) relationship related sources (iii) work-nature and time related sources (iv) organizational policy and position related sources (v) situation/ environmentally related sources of stress and others.

\begin{tabular}{|c|c|}
\hline Working Characteristics & Stressors \\
\hline Organizational function and culture & $\begin{array}{l}\text { Poor communication, task environment, problem-solving } \\
\text { environment and poor development practices }\end{array}$ \\
\hline Participants & Low participation in decision making \\
\hline Career development and job status & $\begin{array}{l}\text { Career uncertainty, stagnation, poor pay and work status, and } \\
\text { job insecurity or redundancy }\end{array}$ \\
\hline Role in organization & $\begin{array}{l}\text { Role ambiguity, and conflict in role assignment and } \\
\text { performance of task }\end{array}$ \\
\hline Job content & $\begin{array}{l}\text { Ill-defined work, high uncertainty in job process, lack of variety, } \\
\text { fragmentation of work, under-utilization of skills, and physical } \\
\text { constraints. }\end{array}$ \\
\hline Workload and work place & $\begin{array}{l}\text { Work over-load, work under-load, time pressure and deadlines, } \\
\text { lack of control over pacing of work }\end{array}$ \\
\hline Work time & $\begin{array}{l}\text { Inflexible work schedule, unpredictable hours of work, } \\
\text { long hours of work. }\end{array}$ \\
\hline Interpersonal relationship at work & $\begin{array}{l}\text { Social or physical isolation, lack of social support from other } \\
\text { staff, conflict among staff, poor relationship with supervisors } \\
\text { and managers }\end{array}$ \\
\hline Preparation and training & $\begin{array}{l}\text { Inadequate preparation for dealing with more difficult aspect of a } \\
\text { job, Concern about technical knowledge and skill. }\end{array}$ \\
\hline Other problems & $\begin{array}{l}\text { Lack of resources and staff shortages, poor working } \\
\text { environment (e.g. inadequate temperature control, poor lighting, } \\
\text { poor ventilation, etc) }\end{array}$ \\
\hline
\end{tabular}

Table 1 Checklist of work characteristics and stressors

Complied by the authors from different sources including Sutherland and Davidson (1989); Ng et al. (2005); Wahab (2010)

\section{Research Methods}

The survey research method was adopted in this study. The target population was professionals-including architects, builders, civil engineers and quantity surveyors involved in ongoing building construction projects. Kaduna, Ogun and Anambra States representing the North, West and East regions in Nigeria respectively were selected as study areas. A preliminary survey was conducted earlier by the researchers to identify ongoing building construction projects in major urban centres in the selected States. Altogether, 225 ongoing building construction projects of various categories were identified. From that, 20 building projects were randomly selected for the study from each State, representing around $27 \%$ of the identified building projects. Random sampling was used in selecting 185 professionals for the administration of questionnaire. The cross-sectional survey was conducted between January and June 2008 with questionnaires administered to the aforementioned construction professionals working in building construction project sites visited. In order to get responses from the targeted population, some of the building construction sites sampled were visited more than once, and some of the professionals were traced to their offices. Of the 185 questionnaires

Ibem, E 0 et al. (2011) 'Work stress among professionals in the building construction industry in Nigeria', Australasian Journal of Construction Economics and Building, 11 (3) 45-57 
distributed, 114 questionnaires representing around $62 \%$ of the distributed questionnaires were retrieved. However, seven of them were invalid and not used in the analysis.

In developing the questionnaire used in the collection of primary data, extensive review of literature was carried out to identify work stress factors as found in prior studies. The different stressors in building projects were broadly classified according to job demand, physical factors, organizational factors, and job role factors in line with evidence in literature on stress factors in the construction industry in general (Dainty et al., 1999; Lingard and Francis, 2004; Leung et al., 2005; Wahab, 2010). Consequently, the questionnaire was designed based on the goal of the current research as well as findings from the review of literature. The questionnaire contained structured closed and open-ended questions. It was divided into two sections, with each section designed to elicit specific information from the respondents. Section one was designed to elicit information on the personal profiles of the respondents while the section two dwelt basically on perceived work stress factors among professionals. In section two the open-ended question asked the respondents if they have ever experienced work stress in the course of their involvement in building design and construction activities. The closed questions on the other hand dwelt on work related stress factors, physical and environmental induced stress as well as stress due to organizational structures. Respondents were provided with options of the different stress factors as identified in literature and were asked to identify by ticking the stress factors which according to their opinion contributed to their individual experiences of work stress.

The data obtained in the survey was processed and analysed using the SPSS 15 for Windows. Descriptive statistical tools including cross tabulation, frequency count and percentages were used in the analysis of the quantitative data obtained from the close-ended questions while content analysis was used in the analysis of the open-ended questions and secondary data obtained from the review of literature.

\section{Result and Discussion}

\section{Profile of the Respondents}

The result of the analysis shows that around $91 \%$ of the respondents were males as against $9 \%$ who were females. This underscores the dominance of male professionals in the building

\begin{tabular}{|c|c|c|c|c|c|}
\hline Qualifications & Architects & Builders & $\begin{array}{c}\text { Civil } \\
\text { Engineers }\end{array}$ & $\begin{array}{c}\text { Quantity } \\
\text { Surveyors }\end{array}$ & Total (\%) \\
\hline $\begin{array}{c}\text { Full Professional *Registration } \\
\text { (ARCON; CORBON; COREN, }\end{array}$ & 4 & 6 & 8 & 2 & $20(18.5)$ \\
\hline $\begin{array}{c}\text { QSBRN) } \\
{ }^{*} \text { MNIOB/ANIQS }\end{array}$ & - & 15 & - & 3 & $18(17.0)$ \\
\hline Masters Degree & 10 & 5 & 1 & - & $16(15.0)$ \\
\hline Bachelor Degree & 7 & 4 & 14 & 5 & $30(28.0)$ \\
\hline Higher National Diploma & 6 & 3 & 8 & 3 & $20(18.5)$ \\
\hline National Diploma & 0 & 2 & 0 & 1 & $3(3.0)$ \\
\hline Total & $\mathbf{2 7}$ & $\mathbf{3 5}$ & $\mathbf{3 1}$ & $\mathbf{1 4}$ & $\mathbf{1 0 7 ( 1 0 0 )}$ \\
\hline
\end{tabular}

Table 2 Highest academic and professional qualifications of the respondents

Source: Field Survey (2008) *ARCON: Architects Registration Council of Nigeria, CORBON: Council of Registered Builders of Nigeria; COREN: Council for the regulation of Engineering in Nigeria; QSBRN: Quantity Surveyors Board of Registration in Nigeria (Regulatory Bodies for the practice of Architecture, Building Technology, Engineering and Quantity Surveying respectively in Nigeria) MNIOB: Member Nigerian Institute of Building; ANIQS: Associate Nigerian Institution of Quantity Surveyors

Ibem, E 0 et al. (2011) 'Work stress among professionals in the building construction industry in Nigeria', Australasian Journal of Construction Economics and Building, 11 (3) 45-57 
construction industry in the study areas. The result also shows that $31 \%, 24 \%$ and $45 \%$ of the respondents were in construction sites in Anambra, Kaduna and Ogun States respectively. Some $33 \%$ of the respondents were Builders, 29\% Civil/ Structural Engineers, 25\% Architects, and $13 \%$ Quantity Surveyors.

Table 2 shows the distribution of the respondents according to their highest academic and professional qualifications. Around $19 \%$ of the respondents have full professional qualifications while $17 \%$ of them were corporate members of their respective professional bodies getting ready for full professional registration with the different regulatory agencies in Nigeria.

The result (Table 2) also shows that around $43 \%$ of the respondents had academic qualification of a bachelor degree and above, and only 3\%, mainly builders and quantity surveyors had the minimum academic qualification of a National Diploma. The above result shows that a majority of professionals in the building construction industry encountered in the survey were highly qualified personnel. Table 3 shows the distribution of the respondents according to number of years of site experience. Most (67\%) of the respondents had over 10 years of experience, $24 \%$ had between 6 years and 10 years experience, and only $9 \%$ had less than 6 years of professional site experience. This result shows that majority of those interviewed had reasonable years of experience in their respective professions and in building design and construction activities. This suggests that their perception of work stress is based on personal experience.

\begin{tabular}{|c|c|c|c|c|c|}
\hline Site Experience (Years) & Architects & Builders & $\begin{array}{c}\text { Civil } \\
\text { Engineers }\end{array}$ & $\begin{array}{c}\text { Quantity } \\
\text { Surveyors }\end{array}$ & Total (\%) \\
\hline $\mathbf{0 - 5}$ & 5 & 3 & 2 & 0 & $10(9.0)$ \\
\hline $\mathbf{6 - 1 0}$ & 15 & 4 & 6 & 1 & $26(24.0)$ \\
\hline $\mathbf{1 1 - 1 5}$ & 5 & 10 & 10 & 5 & $30(28.0)$ \\
\hline $\mathbf{1 6}$ and Above & 2 & 18 & 13 & 8 & $41(39.0)$ \\
\hline Total & $\mathbf{2 7}$ & $\mathbf{3 5}$ & $\mathbf{3 1}$ & $\mathbf{1 4}$ & $\mathbf{1 0 7}(\mathbf{1 0 0 . 0})$ \\
\hline
\end{tabular}

Table 3 Site experience of the respondents (source: Field work, 2008)

\section{Perception of Work Stress}

Table 4 shows the respondents' perception of work stress on building construction sites. An examination of the result reveals that most (94\%) of the respondents have experienced work stress while $6 \%$ responded that they have not experienced work stress. The fact that such a majority of the respondents had experienced stress as a result of their work suggests that the data obtained on stress factors have a reasonable degree of reliability

\begin{tabular}{|l|c|c|}
\hline Have you ever experienced work stress on building construction Site? & Frequency & Percentage \\
\hline Yes & 101 & 94 \\
\hline No & 6 & 6 \\
\hline Total & $\mathbf{1 0 7}$ & $\mathbf{1 0 0}$ \\
\hline
\end{tabular}

Table 4 Perception of work stress among the professional (Source: Field work, 2008)

\section{Work Demand and Environmental Related Stress Factors}

Figure 1 shows the responses of the professionals on the six work demand related stress factors investigated. The result shows that a high volume of work was the most significant work

Ibem, E 0 et al. (2011) 'Work stress among professionals in the building construction industry in Nigeria', Australasian Journal of Construction Economics and Building, 11 (3) 45-57 
related stress factor as identified by the respondents. This is followed by budget related pressures and ambitious deadlines respectively with $78 \%, 51 \%$ and $50 \%$ of the respondents indicating that these three factors were key sources of work stress.

The result is consistent with evidence in the literature, and it is to be expected for a number of reasons. First is the nature and complexity of building construction work which overloads professionals and workers with work. Second is that a majority of building construction sites sampled were multi-storey buildings and automobile service stations, which involve relatively high volumes of work at all stages. Third is that construction workers in Nigeria are known to work under tight budgets and time frame as most client want immediate delivery of their building projects in order to maximize profit on their investments.

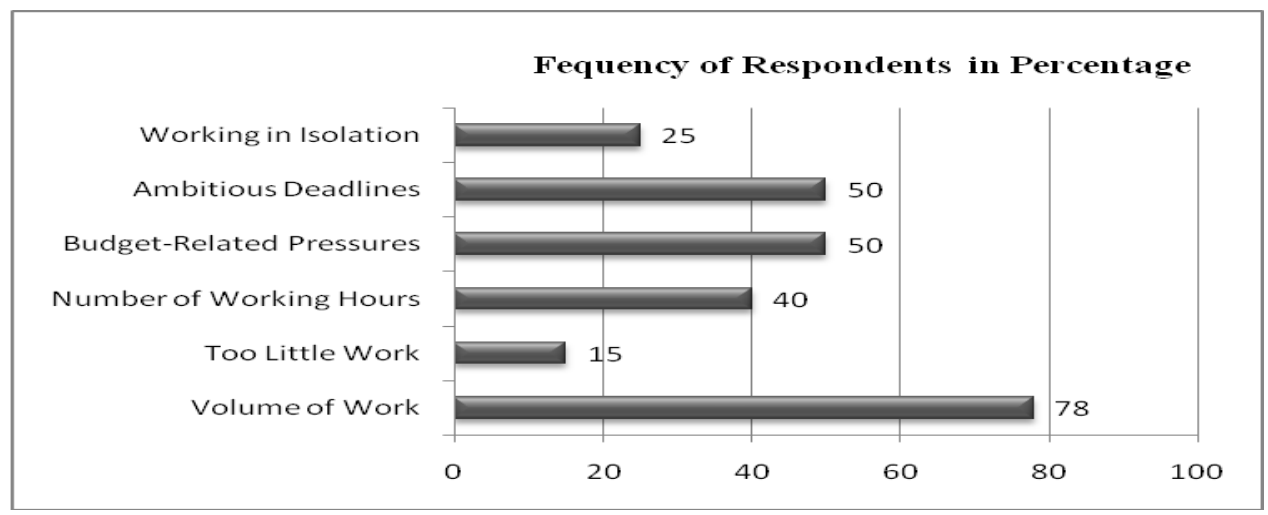

Figure 1 Work demand related stress factors (Source: Field study, 2008)

However, contrary to evidence in the literature suggesting that number of working hours can be a key source of stress, it is obvious from Figure 1 that the number of hours put in by the professionals in the building construction industry sampled in the study areas was not the leading source of stress. This is based on the result which shows that only around $40 \%$ of the respondents indicated that the number of working hours was a source of stress. This result may be explained by noting that the nature of training these professionals received exposed them to the rigours of long hours of strenuous academic and field work, hence long working hours was not viewed as a principal stressor by many of those interviewed.

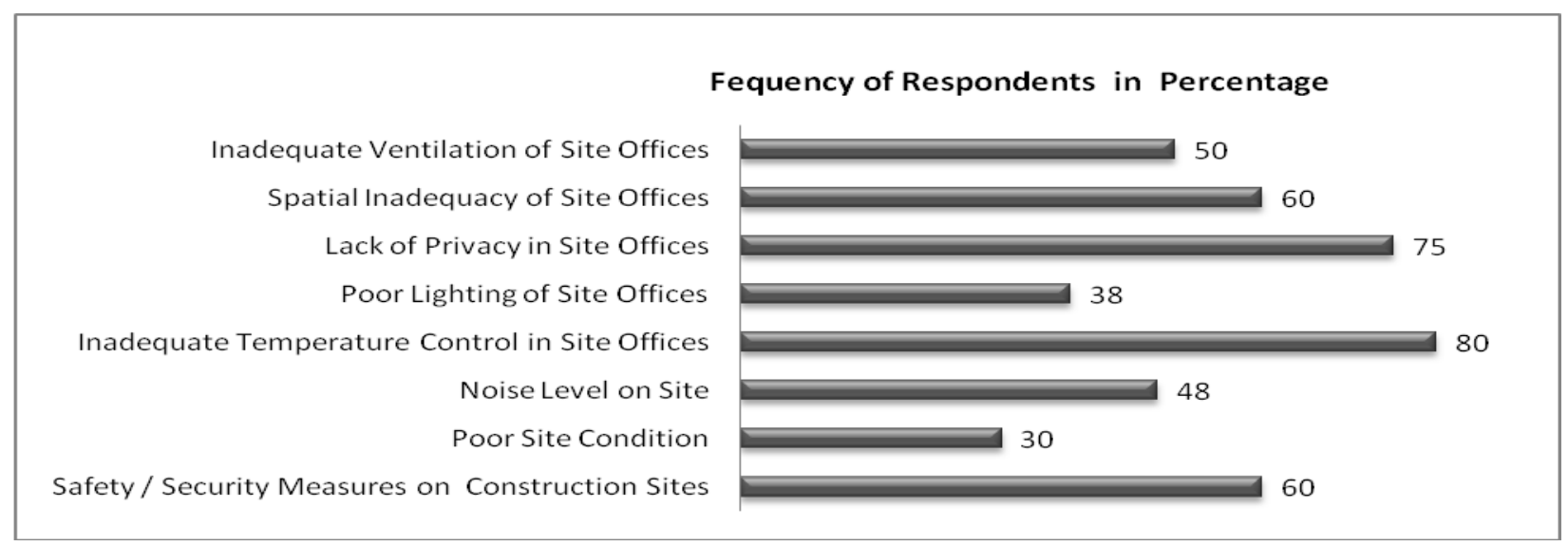

Figure 2 Physical work environment stressors (Source: Field work, 2008)

Ibem, E 0 et al. (2011) 'Work stress among professionals in the building construction industry in Nigeria', Australasian Journal of Construction Economics and Building, 11 (3) 45-57 
Figure 2 shows the respondents' perception of the different physical work environment stressors. It is evident from the result that of the eight physical work environment stressors investigated in this study, inadequate temperature control in site offices was the key source of stress among the professionals sampled. Eighty per cent of the respondents identified inadequate temperature control in site offices as the key work environment related stressor. This is followed by lack of privacy in site offices (75\%); safety/security measures on construction sites and spatial inadequacy of site offices (60\%) as well as inadequate ventilation of site offices (50\%).

This result suggest that building construction sites in Nigeria are characterised by inadequacies in space, ventilation, humidity and temperature control measures, which render them not very conducive for productive work. Indeed high temperature as a key stress factor is understandable as Nigeria is in the tropics and experiences temperature as high as $39^{\circ} \mathrm{C}$ during the dry seasons stretching between November and March. It is also evident from the result that poor site condition, noise level and poor lighting of site offices were not critical sources of stress to professionals sampled in the study areas. Although the result suggests that these are challenges; the majority of the respondents did not see them as threats or impediments to the effective discharge of their normal duties. In all, the result of physical work environment related stress appears to provide support for evidence in the literature (Lin and Chan 2009; Wahab, 2010) suggesting that unfavourable working environment is a key source of stress among workers in the construction industry in general.

Figure 3 shows the respondents' perception of stress factors due to their respective professional roles in the building construction process. An examination of this result reveals that $80 \%$ of the respondents indicated that variations in the scope of work was a principal source of stress while fragmentation of work structure was a source of stress to $75 \%$ of those interviewed. It is also evident from the result that $40 \%$ of the respondents claimed that lack of clarity in role was a source of stress while $25 \%$ and $21 \%$ of them indicated that job insecurity and insufficient skills respectively constituted stress to them.

The result as obtained in Figure 3 can be explained within the context of the fact that building projects in Nigeria are most often inundated with variations due to errors in design and/or change in client's need as buildings are being constructed. It can also be linked to the fact that building procurement is generally carried out in professionally divided sections such as architectural, structural, services, cost and others. As a result, the entire building construction process is seen as fragmented. This suggests that specialization among professionals in the building industry can be a source of stress. In fact this is in line with findings (Wahab, 2010) indicating that a specialized job nature contributed to stress among artisans in the construction industry in Nigeria. Other notable stress factor identified in this study is lack of clarity of roles on sites (see Figure 3). The fact that there is often conflict between architects, builders and civil/ structural engineers in building construction sites in Nigeria can help to explain why about $40 \%$ of the respondents claimed that lack of clarity of role constituted a stress factors to them. This can also be linked to organizational factors such as poor planning and communication, which the respondents indicated were among the principal stress factors. In contrast, Job insecurity and insufficient skills were not considered as key sources of stress among the professionals encountered in the survey. This is probably because most of them are highly trained and qualified professionals who are in short supply in Nigeria, and thus job insecurity and insufficient skill are not major concerns. 


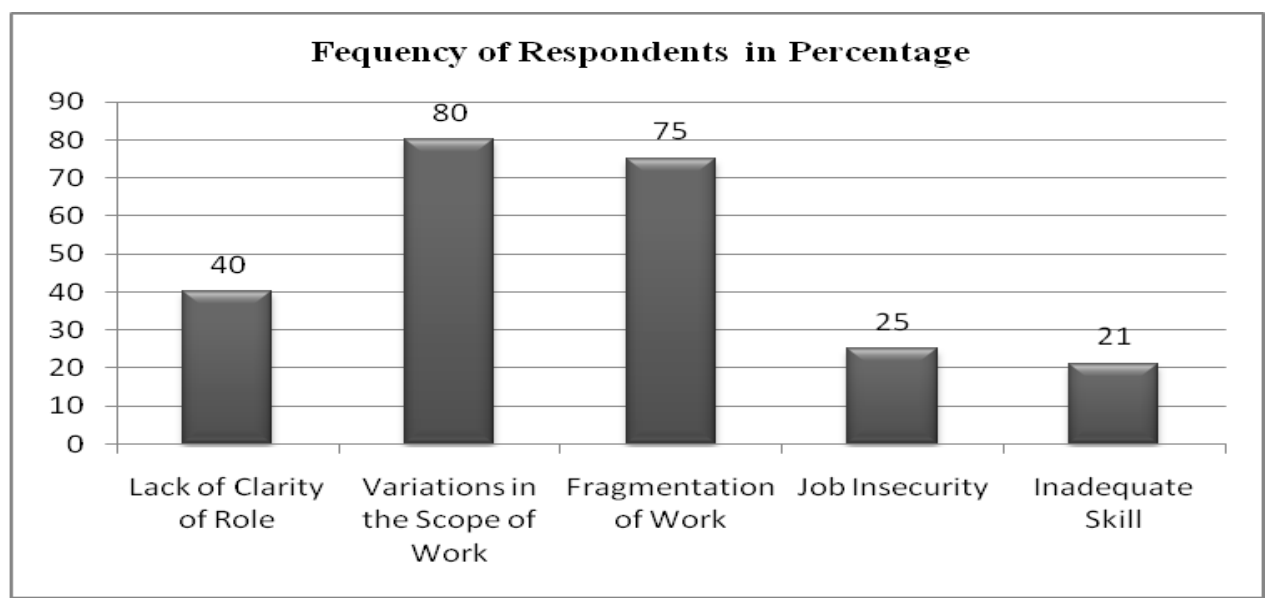

Figure 3 Job role stress factors (Source: Field survey, 2008)

\section{Organizational Related Stress Factors}

Figure 4 shows the result of the eleven organizational related stress factors investigated. It is evident from the result that a majority $(80 \%)$ of the respondents claimed that lack of feedback on the performance of staff members on building projects handled by them was a key source of stress. This is followed by poor communication; inadequate staffing, poor planning and crisis management mechanisms in their respective organizations.

The result on Figure 4 suggests that most building construction and related firms in the study areas are characterised by poor communication, planning and crisis management mechanisms. There are also indications that the building construction firms from where the sample was drawn had challenges of inadequate staffing, lack of proper evaluation and monitoring of staff performance on project sites and inter-personal conflicts as this study suggests.

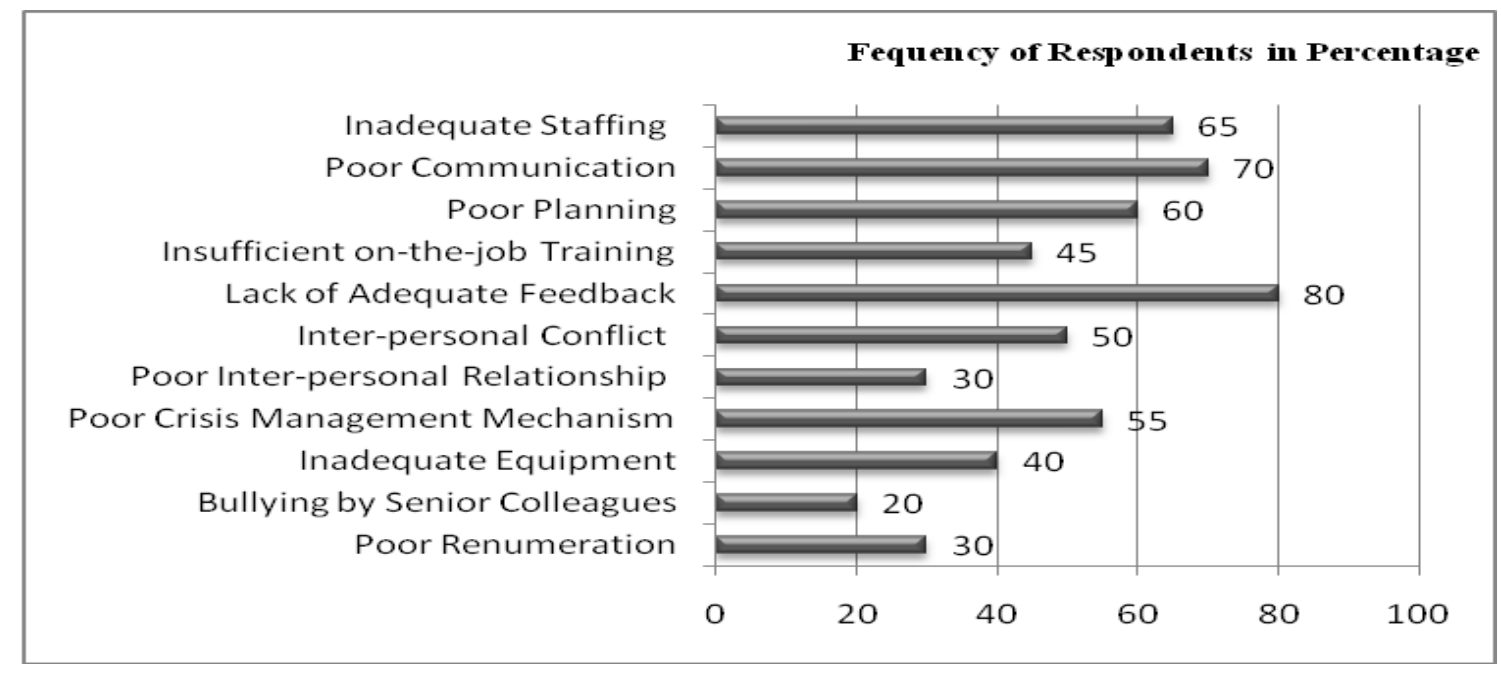

Figure 4 Organizational related stress factors (Source Field survey, 2008)

These inferences were arrived at because these organizational features were perceived as key sources of stress among the professionals sampled. Other organizational related stress factors identified by a reasonable percentage of the professionals sampled were insufficient on-the-job training and inadequate equipment. It is evident from the above result, that most of the organizational related stress factors borders on bureaucracy, which $\mathrm{Ng}$ et al. (2005) noted was

Ibem, E 0 et al. (2011) 'Work stress among professionals in the building construction industry in Nigeria', Australasian Journal of Construction Economics and Building, 11 (3) 45-57 
the most difficult stressor to manage. Notably, the result however suggests that poor remuneration was not a key source of stress among most professionals in the building industry in the study areas. This appears to be inconsistent with findings in ( $\mathrm{Ng}$ et al., 2005) indicating that poor remuneration was a source of stress among construction workers. This is probably due to the fact that most of those sampled were highly qualified and scare professionals and therefore adequately remunerated.

\section{Conclusions}

This study focused on work stress factors among professional architects, builders, civil/structural engineers and quantity surveyors in the building construction industry in Nigeria. The findings show that the key stress factors among these professionals were high volume of work; lack of thermal comfort, privacy and adequate space in site offices, lack of feedback on previous and ongoing building projects, lack of security/ safety measures on site, variations in the scope of work and fragmentation of building work into specialized fields. Other stress factors related to organizational structure were lack of feedback on staff performance on building projects, poor communication and inadequate staffing and others. Indeed, the research has revealed that, most of the professionals involved in building projects planning and execution in Nigeria experienced work stress from a range of sources.

There is no doubt that the findings of this study have a number of implications that require attention in eliminating or reducing stress factors among professionals in the building construction industry in Nigeria. As people perceive stress factors differently so also do professionals in the building construction industry in Nigeria; therefore, a number of mitigation measures may be considered.

First, it is important for building contractors to work closely with architects, cost consultants and clients to arrive at realistic budgets and deadlines for job delivery at the design stage of building projects, if the aim is to reduce the incidence of avoidable pressures associated with meeting ambitious deadlines, which most often may lead to stress, poor quality job and low productivity.

Second, construction firms aiming to reduce stress should give adequate attention to the comfort of professionals working on building construction sites. Pragmatic and workable strategies are needed to improve the level of security and physical working environment of professionals on building construction sites. This calls for deliberate policies by organizations in the building industry to improve employees' working conditions and evaluate their performance to develop confidence among professionals in coping with challenges of work stress.

Furthermore, variations in the scope of work while the construction work is in progress can be reduced by engaging appropriate job design practices which ensures minimum variations due to human errors. The involvement of all the professionals at the design and construction stages of building projects could ensure that tasks performed by the different professionals are identified as a whole unit of a job rather than as fragments.

\section{References}

Aitken, A., and Crawford, L. (2007) 'Coping with stress: Dispositional coping strategies of project managers', International Journal of Project Management, 25, 666-673

Anderson, J.R. (1976) Language, Memory and Thought, Hillsdale, New Jersey, Lawrence Eribaum Associates Publishers

Brown, J. D. (2001) Using Surveys in Language Programs, Cambridge University Press, Cambridge

Ibem, E 0 et al. (2011) 'Work stress among professionals in the building construction industry in Nigeria', Australasian Journal of Construction Economics and Building, 11 (3) 45-57 
Campbell, F. (2006) Occupational Stress in the Construction Industry, Berkshire, UK: Chartered Institute of Building

Chan, Y.S.I and Leung, M.Y. (2009) Optimizing Stress and Performance of Hong Kong Construction Professionals, VDM Verlag, Germany

Cox, T and Mackay, C.J. (ed) (1979) Response to Stress - Occupational Aspects, Guildford: IPC Science \& Technology Press

Dainty, A. R. J., Neale, R. H. and Bagilhole, B.M. (1999) 'Women's careers in large construction companies: Expectations unfulfilled?', Career Development, International, 4 (7), 353-357

Goldenhar, L., Williams, L. and Swanson, N. (2003) 'Modeling relationships between job stressors and injury and near-miss outcomes for construction labourers', Journal of Work and Stress, 17 (3), 218-240

Halkos, G and Bousinakis, D. (2010) 'The effect of stress and satisfaction on productivity', International Journal of Productivity and Performance Management, 59 (5), 415 - 431

Haq, Z., lqbal, Z., and Rahman, A. (2008) 'Job stress among community health workers: A multi-method study from Pakistan', International Journal of Mental Health Systems, 15 (2), 1-8

Health and Safety Executive (2007) Tackling Work Related Stress: A Manger's Guide to Improving and Maintaining Employee Health and Well-Being. Sudbury: HSE Books

Karasek, R.A.Jr. and Theorell, T. (1990) Healthy Work: Stress, Productivity, and the Reconstruction of Working Life. New York: Basic Books

Kenneth, H.R. (2005) Project Quality Management - Why, What and How, E-books on-line, J.R. Publishing

Lath, S.K. (2010) 'A Study of the occupational stress among teachers', International Journal of Education Administration, 2 (2), 421-432

Larzarus, R.S. (1966) Psychological Stress and the Coping Process, McGraw-Hills, New York

Leiter, M. P. (1991) 'Coping Patterns as Predictors of Burnout: The Function of Control and Escapist Coping Patterns', Journal of Organisational Behavior, 12 (2), 123-144

Leung, M.Y., Chan Y.S. and Yuen K.W. (2010) 'Impacts of stressors and stress on the injury incidents of construction workers in Hong Kong', Journal of Construction Engineering and Management, ASCE, 136 (10), 1093-1103

Leung, M.Y., Chan Y.S., Chong A. and Shem J. (2008) 'Developing structural integrated stressor-stress models for client's and contractor's cost engineers', Construction Engineering and Management, ASCE, 134 (8), 635-643

Leung, M.Y., Sham J. and Chan Y.S. (2007) 'Adjusting stressors - job demand stress in preventing rustout/burnout on estimators', Surveying and Built Environment, 18 (1), 17-26

Leung, M. Y., Ng, S. T., Skitmore, M. and Cheung, S. O. (2005) 'Critical stressors influencing construction estimators in Hong Kong', Construction Management and Economics, 23, 33-43

Lin, R and Chan, C (2009) 'Effects of heat on workers' health and productivity in Taiwan', Journal of Global Health Action, .2, 1-6, viewed $16^{\text {th }}$ May, 2010 www.globalhealthaction. net/index.php/gha/article/view/2024/255

Lingard, H. and Francis, V. (2004) 'The work-life experiences of office and site-based employees in the Australian construction industry', Construction Management and Economics, 22, 991-1002 
Lingard, H., Yip, B., Rowlinson, S. and Kvan, T. (2006) 'Burnout among future construction professionals: a cross-national study', Construction Management and Economics, 24, 335-337

Loosemore, M. and Waters, T. (2004) 'Gender difference in occupational stress among professionals in the construction industry', Journal of Management in Engineering, 20 (3), 126132

McVicar, A. (2003) 'Workplace stress in nursing: A literature review', Journal of Advanced Nursing, 44 (6), 633-642

Martino, V.D and Musri, M (2001) Guidance for the Prevention of Stress and Violence at Work Place. Kuala Lumpur, Department of Occupational Safety and Health, Malaysia

Maslach, C., Jackson, S. E. and Leiter, M. P. (1996) Maslach Burnout Inventory Manual, $3^{\text {rd }}$ ed, Palo Alto, CA, Consulting Psychologists Press

Maslach, C. Schaufeli, W. B. and Leiter, M. P. (2001) 'Job burnout', Annual Review of Psychology, 52, 397-422

Melia, J.L. and Becerril, M. (2007) 'Psychological sources of stress and burnout in the construction sector: A structural equation model', Psicothema, 19 (4), 679-686

Ng, S.T., Skitmore, R. M. and Leung, T. K. (2005) 'Manageability of stress among construction project participants', Engineering, Construction and Architectural Management, 12 (3) 264-282

Pulat, B. (1997) Fundamentals of Industrial Ergonomics, $2^{\text {nd }}$ ed, Prosect Heights, Illinois, Waveland Press

Statt, D.A. (1994) Psychology and the World of Work, Basingstoke, Macmillan

Seyle, H. (1978) The Stress of Life, $2^{\text {nd }}$ ed, New York, McGraw-Hills

Somerfield, M. R. and McCrae, R. R. (2000) 'Stress and coping research', American Psychologist, 55 (6) 620-625

Sutherland, V and Davidson, M. (1989) 'Stress among construction site managers - a preliminary study', Stress Medicine, 5, 221-235

Wahab, A. B (2010) 'Stress management among artisans in construction industry in Nigeria', Global Journal of Researches in Engineering, 10 (1) 93-103

Whetten, D. A. and Cameron, K. S. (1991) Developing Management Skills, $2^{\text {nd }}$ ed, Harper Collins, New York, NY, 23-35

Wong, J., Toe, M.and Cheng, Y. K. (2010) 'Cultural determinants of stress in the construction industry' in Proceedings of 2010 International Conference on Construction and Real Estate Management, 1-3 December 2010, Brisbane, Queensland, viewed 12 ${ }^{\text {th }}$ March, 2011 from http://eprints.qut.edu.au/

Yip, B., Rowlinson, S., Kvan, T. and Lingard, H. (2005) 'Job burnout within the Hong Kong construction industry: A cultural perspective' in Proceedings of the CIB W92/T23/W107 International Symposium on Procurement Systems held at Las Vegas, Nevada, USA 